\title{
Study of thermodynamic water properties and moisture sorption hysteresis of mango skin
}

\author{
Silvio José Ferreira de SOUZA ${ }^{1}$ Aline Inácio ALVES², Érica Nascif Rufino VIEIRA², \\ José Antônio Gomez VIEIRA ${ }^{1}$, Afonso Mota RAMOS², Javier TELIS-ROMERO ${ }^{1 \star}$
}

\begin{abstract}
The equilibrium moisture content for adsorption and desorption isotherms of mango skin was determined using the static gravimetric method at temperatures of $20,26,33,38$ and $44^{\circ} \mathrm{C}$ in the 0.056 to 0.873 water activity range. Both sorption curves show a decrease in equilibrium moisture content as the temperature increasing. The hysteresis effect was observed at constant water activity. The Guggenheim, Anderson, and de Boer (GAB) model presented the best fitting accuracy among a group of models and was used to determine the thermodynamic properties of water sorption. Integral enthalpy and integral entropy areas showed inverted values for the adsorption and desorption isotherms over the wide range of water activity studied. These values confirm, in energetic terms, the difference between adsorption and desorption isotherms observed in the hysteresis phenomenon. Finally, the Gibbs free energy revealed that the sorption process was spontaneous for both sorption isotherms.

Keywords: agricultural waste; gravimetric method; integral properties; modelling; water content.

Practical Application: This work presents information about the hysteresis characteristics of mango skin as well as their thermodynamic properties of water sorption. The information given in this study can be used for processing, storage, and packaging of this agro-waste. In addition, the combination of classical and modern methodologies is useful for determining the best stability conditions over a range of water activity and equilibrium moisture content.
\end{abstract}

\section{Introduction}

Among tropical fruits, mango (Mangifera indica) is one of the most appreciated for consumption as well as study and research (Bon et al., 2010; Rangel-Marrón et al., 2011). The fruit, which surrounds the kernel containing the seed, presents a yellow or orange flesh with a fibril structure. Mango pulp contains about $14 \%$ of total sugars, with sucrose being the main constituent followed by vitamin C (37 mg/100 g), minerals such as riboflavin, niacin, calcium, phosphorus, iron and a considerable amount of carotenes (Vaughan \& Geissler, 2009; Rangel-Marrón et al., 2011; Bello-Pérez et al., 2005). Mango processing produces byproducts such as peels and kernels. The skin comprises $15-20 \%$ of the fruit (Beerh et al., 1976). Since the skin is not used for any commercial purpose, it is discarded as a waste and becomes a source of pollution. Mango skin contains a number of compounds of high added value, such as polyphenols, carotenoids, enzymes and dietary fiber (Ajila et al., 2007), but studies on skins are limited.

The structure and composition of a food material play a key role in its sorption behavior. Experimental studies are required to elucidate this phenomenon in complex systems such as food, providing important information on the hygroscopic state of the amorphous structure in fruit (Al-Muhtaseb et al., 2004). Knowledge of the physicochemical nature of water bounded in the solid matrix is fundamental for understanding the effects of water content and storage conditions on food stability. Certain thermodynamic parameters can be estimated from the sorption isotherms and this information is useful for understanding the physicochemical binding of water when the product is subjected to different temperatures and relative humidity conditions (Azuara \& Beristain, 2006). Properties such as enthalpy, entropy and Gibbs free energy are useful for explaining reactions and phenomena at the molecular level in materials. Furthermore, the hydrophobic and hydrophilic interactions between water and other molecules can be explained from the linear correlation of entropic and enthalpic mechanisms and the pore-water interaction (Azuara \& Beristain, 2006; Labuza et al., 1985).

This work aims to study the thermodynamic properties of water and hysteresis behavior from adsorption and desorption isotherms of mango skin.

\section{Materials and methods}

\subsection{Raw material}

Mango skin samples (Mangifera indica L. cv. Tommy Atkins) were used in this study. Overripe mango in disposal condition was obtained from a local juice processing facility in São José do Rio Preto (São Paulo, Brazil). 


\subsection{Sample preparation}

Once overripe mango was cleaned and disinfected, the skin was separated from the pulp using a food grinder (model RI17625/71, Philips, Japan) to reduce particle size to 0.1 to $0.5 \mathrm{~mm} \pm 0.05 \mathrm{~mm}$. Two hundred fifty grams of the grinded samples were dried in a thin layer at $40{ }^{\circ} \mathrm{C}$ using a forced-air convective dryer at $2.0 \mathrm{~m} / \mathrm{s}$ for 10 hours. To ensure homogenous moisture content in the material, the sample was periodically stirred during drying with the dried sample stored in hermetic glass jars for further analysis. Dried and ground fresh mango skin samples were used to construct the adsorption and desorption isotherms. The initial moisture content of the mango skin was $0.78 \mathrm{~kg} / \mathrm{kg}$ of wet basis (w.b) as determined in a vacuum oven according to the AOAC method 934.06 (Association of Analytical Chemists International, 1997).

\subsection{Adsorption and desorption isotherms}

The equilibrium moisture content of the dried and fresh mango skin were determined using the static gravimetric method (Jowitt et al., 1987) at temperatures of $20,26,33,38$ and $44^{\circ} \mathrm{C}$. The experimental setup consisted of eleven hermetic glass jars containing different saturated salt solutions, corresponding to values of water activity $\left(a_{w}\right)$ between 0.056 and 0.873 . Each jar was filled to a depth of $1.5 \mathrm{~cm}$ with the appropriate salt solution. Three small plastic containers containing the dried sample (1 g) and fresh sample (1 g) were placed in the jars; thus, three replicates of the same experiment were performed. The jars were placed in a temperature-controlled chamber model TE-391 (Tecnal, Piracicaba, Brazil) at different temperatures. The sample weights were measured until the moisture content was less than $0.1 \%$ of dry basis (d.b.) (time elapsed from 4 to 5 weeks). This point was considered equilibrium, thus ensuring that the water activity of each sample corresponded to the water activity fixed by the salt. For each sample, the initial moisture content was determined by vacuum oven to determine the equilibrium moisture content from the registered weight up to equilibrium. The values obtained for the equilibrium moisture contents, water activities, and temperatures were used to construct both adsorption and desorption isotherms for the mango skin.

\subsection{Modelling adsorption and desorption isotherms}

Both types of sorption isotherms for mango skin were simulated using the theoretical models of Guggenheim, Anderson and de Boer (GAB) (Equation 1) and Brunauer, Emmett and Teller (BET) (Equation 2) as well as the empirical models of Halsey (Equation 3), Iglesias-Chirife (Equation 4) and Oswin (Equation 5). In the models, the moisture content was described as a function of both temperature and water activity (Bahloul et al., 2008; Goula et al., 2008; Pagano \& Mascheroni, 2005; Iglesias \& Chirife, 1976; Timmermann et al., 2001).

$$
\begin{aligned}
& X=\frac{X_{m} C K a_{w}}{\left(1-K a_{w}\right)\left(1+(C-1) K a_{w}\right)} \\
& X=\frac{X_{m} C a_{w}}{\left[\left(1-a_{w}\right)\left(1+(C-1) a_{w}\right)\right]}
\end{aligned}
$$

$$
\begin{aligned}
& X=\left[\frac{\exp (a-b T)}{-\ln \left(a_{w}\right)}\right]^{\frac{1}{c}} \\
& X=(a+b T)\left[\frac{a_{w}}{\left(1-a_{w}\right)}\right]+c \\
& X=(a+b T)\left[\frac{a_{w}}{\left(1-a_{w}\right)}\right]^{\frac{1}{c}}
\end{aligned}
$$

where $a, b$ and $c$ are the constants of the empirical models, $a_{w}$ is the water activity (dimensionless), $X$ is the equilibrium moisture content $\left(\mathrm{kg} / \mathrm{kg}\right.$, d.b.) and $X_{m}$ is the average equilibrium water content of the monolayer from GAB and BET models $(\mathrm{kg} / \mathrm{kg}$, d.b.). For the GAB and BET theoretical models, the constants can be written according to Equations 6 and 7:

$$
C=C_{0} \exp \left(\frac{H_{m}-H_{n}}{R T}\right)
$$

$K=K_{0} \exp \left(\frac{\lambda-H_{n}}{R T}\right)$

where $C_{0}$ is the GAB and BET models parameter, $K_{0}$ is the GAB model parameter, $H_{m}$ and $H_{n}$ are the water sorption heats of the monolayer and multilayer $(\mathrm{kJ} / \mathrm{mol}), \lambda$ is the vaporization energy of pure water $(\mathrm{kJ} / \mathrm{mol}), T$ is the absolute temperature (K) and $R$ is the ideal gas constant $(8.314 \mathrm{~kJ} / \mathrm{kmol} \mathrm{K})$. In Equation 6 the constant $C$ from the BET model represents the logarithmic difference between the chemical potential of the sorbate molecules in the pure liquid state and the first sorption layer, while representing the difference in the upper layers and monolayer in the GAB model; while the constant $K$ is related to the difference in the sorbate pure liquid state and in the upper layers. The product of both constants, $C$ and $K$, from the GAB model represents the equivalent of the constant $C$ from the BET model (Timmermann et al., 2001; Rizvi, 2005).

Theoretical parameters $\left(X_{m}, C_{0}, K_{0}, H_{m}, H_{n}\right)$ and empirical parameters $(a, b, c)$ were estimated by fitting the equations to the experimental data using the "nlinfit" and "nlparci" functions of the Statistic Toolbox of Matlab 7.1 (The MathWorks Inc., Natick, MA, USA) and considering the "robust" fitting option. The "nilinfit" and "nlparci" functions were used to perform nonlinear regression and determine the confidence intervals of the regression with $\alpha=95 \%$. Residual analyses and normal distributions were determined for the best fitted model using the "lilietest" function.

The adjusted coefficient of determination $\left(R_{a d j}^{2}\right)$ Equation 8 and the root mean square error (RMSE) Equation 9 were used to evaluate the goodness of fit and the accuracy of the estimation, respectively (Cano-Higuita et al., 2015; Villa-Vélez et al., 2012).

$$
\begin{aligned}
& R_{a d j}^{2}=1-\left(\frac{n-1}{n-n_{p}}\right)\left(1-R^{2}\right) \\
& R M S E=\left[\frac{1}{n} \sum_{i=1}^{n}\left(X_{i}-X_{i}^{*}\right)^{2}\right]^{1 / 2}
\end{aligned}
$$

where $R^{2}$ is the coefficient of determination between experimental and estimated values by the corresponding model, $X$ and $X^{*}$ represent the experimental values and the estimated values, $n$ is the number of experimental values and $n_{p}$ is the number of model parameters. 


\subsection{Thermodynamic properties of water sorption}

For both adsorption and desorption isotherms, thermodynamic properties calculations were carried out to estimate the properties at the maximum and minimum temperature levels in the study (Cano-Higuita et al., 2015; Villa-Vélez et al., 2012). Integral properties were determined (Rizvi, 2005). The net integral heat (enthalpy) of sorption, which indicates the binding strength of water molecules to food particles, can be estimated using Equation 10:

$\left[\frac{\partial \ln \left(a_{w}\right)}{\partial(1 / T)}\right]_{\pi}=\frac{\Delta H_{\text {int }}}{R}$

In Equation $10 \Delta H_{\text {int }}$ is the molar equilibrium enthalpy of sorption (integral enthalpy, J/mol) at a constant potential surface, also called diffusion pressure or spreading pressure $\left(\mathrm{J} / \mathrm{m}^{2}\right)$, defined by Equation 11 (McMinn et al., 2005):

$$
\pi=\frac{k T}{A_{m}} \int_{0}^{a_{w}} \frac{X}{a_{w}} d a_{w}
$$

where $k$ is the Boltzmann's constant $\left(1.380 \times 10^{-23} \mathrm{~J} / \mathrm{K}\right)$ and $A_{m}$ is the water molecule area $\left(1.06 \times 10^{-19} \mathrm{~m}^{2}\right)$ (Nezbeda \& Weingerl, 2001). Calculated values of $\pi$ were obtained by optimization from the calculated equilibrium water content given by the best fitting model obtained in the range of $a_{w}$ at different temperatures in the study.

When values for $\Delta H_{\text {int }}$ are obtained, the changes in the molar integral entropy can be calculated using Equation 12:

$\Delta S_{\text {int }}=\frac{-\Delta H_{\text {int }}-R T \ln a_{w}}{T}$

where $\Delta S_{\text {int }}$ is the integral entropy of water adsorbed in the food (J/mol K) (Majd et al., 2012). The free energy for water adsorption $(\Delta G, \mathrm{~kJ} / \mathrm{mol})$, which is an indicator of the characteristics of the water sorption reaction in the system, was calculated by the Gibbs equation (Equation 13) (Rizvi, 2005):

$$
\Delta G=R T \ln \left(a_{w}\right)
$$

\section{Results and discussion}

\subsection{Experimental adsorption and desorption isotherms}

Table 1 shows the experimental results of equilibrium moisture content for the respective adsorption and desorption isotherms.

In Table 1, the equilibrium moisture content ranged from 0.000 to $0.507 \mathrm{~kg} / \mathrm{kg} \mathrm{d.b}$. for adsorption isotherms and 0.000 to $0.622 \mathrm{~kg} / \mathrm{kg}$ d.b. for desorption isotherm, across the whole range of water activities studied. For both adsorption and desorption isotherms of mango skin at a temperature of $20^{\circ} \mathrm{C}$ and $a_{w}=0.873$, maximum equilibrium moisture contents of 0.507 and 0.622 were obtained. These values decrease while temperature increases and at $44^{\circ} \mathrm{C}$ and $a_{w}=0.794$ the equilibrium moisture content values reach 0.183 and $0.203 \mathrm{~kg} / \mathrm{kg}$ d.b. for adsorption and desorption isotherms. This behavior can be attributed to the carbohydrates (Ojokoh, 2007) and fiber content (Larrauri et al., 1996) present in mango skin. At lower temperatures, when the system saturation pressure is lower, the product may be more able to absorb water (Gomez-Carracedo et al., 2010).
To explain the strong relationship between temperature and equilibrium moisture content, some research has indicated that the decrease in moisture content is due to the increase

Table 1. Experimental equilibrium moisture content of mango skin ${ }^{\star}$ as

\begin{tabular}{|c|c|c|c|}
\hline \multirow{2}{*}{$T\left({ }^{\circ} \mathrm{C}\right)$} & \multirow{2}{*}{$a_{w}$} & \multicolumn{2}{|c|}{$X$ (kg/kg, d.b.) } \\
\hline & & Adsorption & Desorption \\
\hline \multirow{12}{*}{20} & 0.000 & $0.000 \pm 0.000$ & $0.000 \pm 0.000$ \\
\hline & 0.066 & $0.005 \pm 0.000$ & $0.007 \pm 0.001$ \\
\hline & 0.118 & $0.011 \pm 0.002$ & $0.012 \pm 0.001$ \\
\hline & 0.138 & $0.009 \pm 0.000$ & $0.015 \pm 0.001$ \\
\hline & 0.249 & $0.023 \pm 0.000$ & $0.031 \pm 0.001$ \\
\hline & 0.329 & $0.028 \pm 0.001$ & $0.045 \pm 0.003$ \\
\hline & 0.547 & $0.087 \pm 0.010$ & $0.107 \pm 0.005$ \\
\hline & 0.589 & $0.103 \pm 0.012$ & $0.134 \pm 0.007$ \\
\hline & 0.752 & $0.196 \pm 0.031$ & $0.280 \pm 0.025$ \\
\hline & 0.772 & $0.256 \pm 0.040$ & $0.304 \pm 0.019$ \\
\hline & 0.820 & $0.344 \pm 0.054$ & $0.413 \pm 0.026$ \\
\hline & 0.873 & $0.507 \pm 0.046$ & $0.622 \pm 0.022$ \\
\hline \multirow{12}{*}{26} & 0.000 & $0.000 \pm 0.000$ & $0.000 \pm 0.000$ \\
\hline & 0.063 & $0.005 \pm 0.000$ & $0.006 \pm 0.000$ \\
\hline & 0.114 & $0.007 \pm 0.001$ & $0.010 \pm 0.001$ \\
\hline & 0.138 & $0.011 \pm 0.000$ & $0.013 \pm 0.000$ \\
\hline & 0.234 & $0.020 \pm 0.000$ & $0.023 \pm 0.000$ \\
\hline & 0.326 & $0.033 \pm 0.001$ & $0.040 \pm 0.001$ \\
\hline & 0.534 & $0.064 \pm 0.005$ & $0.094 \pm 0.005$ \\
\hline & 0.571 & $0.074 \pm 0.006$ & $0.112 \pm 0.006$ \\
\hline & 0.739 & $0.151 \pm 0.014$ & $0.232 \pm 0.016$ \\
\hline & 0.760 & $0.168 \pm 0.015$ & $0.260 \pm 0.017$ \\
\hline & 0.810 & $0.226 \pm 0.023$ & $0.350 \pm 0.030$ \\
\hline & 0.851 & $0.333 \pm 0.016$ & $0.464 \pm 0.016$ \\
\hline \multirow{12}{*}{33} & 0.000 & $0.000 \pm 0.000$ & $0.000 \pm 0.000$ \\
\hline & 0.060 & $0.004 \pm 0.000$ & $0.004 \pm 0.000$ \\
\hline & 0.109 & $0.006 \pm 0.000$ & $0.011 \pm 0.001$ \\
\hline & 0.137 & $0.010 \pm 0.001$ & $0.009 \pm 0.001$ \\
\hline & 0.220 & $0.017 \pm 0.000$ & $0.020 \pm 0.000$ \\
\hline & 0.322 & $0.029 \pm 0.001$ & $0.028 \pm 0.001$ \\
\hline & 0.519 & $0.054 \pm 0.002$ & $0.080 \pm 0.003$ \\
\hline & 0.552 & $0.062 \pm 0.001$ & $0.091 \pm 0.003$ \\
\hline & 0.725 & $0.125 \pm 0.001$ & $0.175 \pm 0.003$ \\
\hline & 0.747 & $0.140 \pm 0.003$ & $0.230 \pm 0.007$ \\
\hline & 0.800 & $0.190 \pm 0.004$ & $0.311 \pm 0.007$ \\
\hline & 0.828 & $0.251 \pm 0.006$ & $0.366 \pm 0.009$ \\
\hline \multirow{12}{*}{38} & 0.000 & $0.000 \pm 0.000$ & $0.000 \pm 0.000$ \\
\hline & 0.059 & $0.003 \pm 0.001$ & $0.004 \pm 0.000$ \\
\hline & 0.106 & $0.007 \pm 0.001$ & $0.006 \pm 0.001$ \\
\hline & 0.136 & $0.009 \pm 0.001$ & $0.011 \pm 0.000$ \\
\hline & 0.210 & $0.014 \pm 0.000$ & $0.018 \pm 0.000$ \\
\hline & 0.319 & $0.025 \pm 0.000$ & $0.033 \pm 0.001$ \\
\hline & 0.510 & $0.055 \pm 0.001$ & $0.059 \pm 0.003$ \\
\hline & 0.540 & $0.062 \pm 0.001$ & $0.067 \pm 0.002$ \\
\hline & 0.715 & $0.136 \pm 0.000$ & $0.135 \pm 0.003$ \\
\hline & 0.738 & $0.156 \pm 0.001$ & $0.152 \pm 0.005$ \\
\hline & 0.793 & $0.189 \pm 0.001$ & $0.206 \pm 0.004$ \\
\hline & 0.812 & $0.248 \pm 0.003$ & $0.256 \pm 0.001$ \\
\hline
\end{tabular}
a function of water activity and temperature.

${ }^{*}$ Mean and standard deviation of the triplicate. 
Table 1. Continued...

\begin{tabular}{cccc}
\hline \multirow{2}{*}{$T\left({ }^{\circ} \mathrm{C}\right)$} & $\mathrm{a}_{\mathrm{w}}$ & \multicolumn{2}{c}{$X(\mathrm{~kg} / \mathrm{kg}$, d.b. $)$} \\
\cline { 3 - 4 } & 0.000 & $0.000 \pm 0.000$ & $0.000 \pm 0.000$ \\
& 0.056 & $0.003 \pm 0.000$ & $0.004 \pm 0.000$ \\
& 0.103 & $0.005 \pm 0.000$ & $0.006 \pm 0.000$ \\
& 0.135 & $0.008 \pm 0.000$ & $0.010 \pm 0.000$ \\
44 & 0.199 & $0.011 \pm 0.000$ & $0.015 \pm 0.000$ \\
& 0.316 & $0.021 \pm 0.000$ & $0.029 \pm 0.001$ \\
& 0.499 & $0.043 \pm 0.002$ & $0.050 \pm 0.003$ \\
& 0.525 & $0.056 \pm 0.003$ & $0.056 \pm 0.003$ \\
& 0.704 & $0.107 \pm 0.007$ & $0.114 \pm 0.008$ \\
& 0.727 & $0.116 \pm 0.008$ & $0.128 \pm 0.009$ \\
& 0.784 & $0.177 \pm 0.015$ & $0.174 \pm 0.013$ \\
& 0.794 & $0.183 \pm 0.007$ & $0.203 \pm 0.009$ \\
\hline
\end{tabular}

${ }^{*}$ Mean and standard deviation of the triplicate.

in the excited state of water molecules at high temperatures, increasing the distances between molecules and reducing their attraction forces (Flores-Andrade et al., 2009; Beristain et al., 1996). Other studies suggest the temperature increase causes water incorporation, which reduces the number of active sites and promotes physical or chemical changes in the studied material (Al-Muhtaseb et al., 2002; Samapundo et al., 2007; Cano-Higuita et al., 2015).

The results reported in the literature for equilibrium moisture content for products such as persimmon skin for adsorption $(0.013-0.447 \mathrm{~kg} / \mathrm{kg}$ d.b. $)$ and desorption $(0.013-0.469 \mathrm{~kg} / \mathrm{kg}$ d.b) isotherms (Telis et al., 2000), jackfruit peel for desorption isotherms $(0.003-0.151 \mathrm{~kg} / \mathrm{kg}$ d.b.) (Prette et al., 2013) and banana peel for desorption isotherms $(0.006-0.532 \mathrm{~kg} / \mathrm{kg}$ d.b.) (Villa-Vélez et al., 2012) were similar to the experimental values of the sorption isotherms obtained for mango skin.

\subsection{Modelling adsorption and desorption isotherms}

The adsorption and desorption isotherms of the mango skin were modeled using the GAB and BET theoretical models and the empirical models of Halsey, Iglesias \& Chirife and Oswin. Table 2 shows the fitting results and the statistical validations for all models. Statistical results show the theoretical and empirical models to be accurate, with $R_{a d j}^{2}>0.978$ and $\left.R M S E<0.018\right)$ indicative of a satisfactory agreement between the experimental and calculated values using these models.

In general terms, all models can be used to describe the equilibrium moisture content behavior over the range of water activities and temperatures studied. Among the goodness of the fit models, the GAB model was selected for this work due to the parameters representing thermodynamic quantities from monolayer and multilayer sorption. Furthermore, the statistical results of $R_{a d j}^{2}$ and $R M S E$ indicate a good adjustment of the experimental data with the model parameters and the closeness of experimental and calculated data, confirmed with the residual analyses and the normal distribution data from Figure 1.
In the GAB model, the $X_{\text {w }}$ parameter was nearly constant for all temperatures. The values of $K$ calculated with the parameters in Table 2 from Equation 1 decreased as the temperature increased (Table 3) For mango skin, the values for the constant $K$ were less than one, indicating a difference in free enthalpy between the sorbate molecules in the pure liquid and those in the second sorption stage in the layer above the monolayer (Gabas et al., 2007; Eim et al., 2011; Mulet et al., 2002). It is also noteworthy that in all cases the values of $C$ and $K$ decreased significantly with increasing temperature, which is in accordance with the Arrhenius relationships Equations 6 and 7 describe the temperature dependence of these parameters. The estimated values of the relationship $\left(H_{m}-H_{n}\right)$ were negative for the adsorption isotherm and positive for the desorption isotherms, indicating endothermic and exothermic interactions of water vapor with primary sorption sites of dried and fresh mango skin, respectively. On the other hand, the values of the relationship $\left(\lambda-H_{n}\right)$ were smaller and positive, which is in agreement with the literature (Al-Muhtaseb et al., 2004). These values, when added to the heat of condensation, provide an estimate of the heat required to desorb one monolayer. According to Iglesias \& Chirife (1976) the parameter $C$ and the monolayer water content $X_{m}$ are substantially dependent on temperature and a small error in their calculation may result in significant differences in the sorption enthalpy value.

\subsection{Hysteresis behavior from adsorption and desorption isotherms}

The comparisons between adsorption isotherms and desorption isotherms of mango skin at temperatures of 20,26, 33,38 and $44^{\circ} \mathrm{C}$ are shown in Figure 2. Both sorption isotherms curves follow the type III isotherm (Brunauer et al., 1940), which adsorbs small amounts of water at low water activities. At lower water activities, water can be adsorbed only to the surface $-\mathrm{OH}$ sites of crystalline sugar, proteins and polysaccharides (Labuza et al., 1985). The hysteresis phenomenon was shown using the calculated equilibrium moisture content from the GAB model, observing that at constant water activity, the equilibrium moisture content was higher for the desorption curve than for adsorption. Similar behavior was reported for red chillies (Kaleemullah \& Kailappan, 2004), crushed chillies (Arslan \& Togrul, 2005), orange peel and leaves (Bejar et al., 2012) and banana (Yan et al., 2008). The hysteresis was observed over the entire water activity range studied but decreases when the temperature increases.

It is known that sorption hysteresis is affected by temperature, component properties, equilibration methods and material structures (Yan et al., 2008). High hysteresis values were found from $0.550-0.800 a_{w}$ at temperatures from 20 to $26^{\circ} \mathrm{C}$, with the values declining sharply from $0.600-0.750 a_{w}$ at $33^{\circ} \mathrm{C}$ and $0.650-0.700 a_{w}$ at 38 and $44{ }^{\circ} \mathrm{C}$.

The magnitude of hysteresis was lower at $44^{\circ} \mathrm{C}$ than at $20^{\circ} \mathrm{C}$, probably due to increased capillary wall elasticity and greater ability to form hydrogen bonds between protein/carbohydrate and water in the structure of mango skin. These observations were documented by Al Hodali (1997) considering a pore tied around by a small capillary rigid structure. During adsorption, 
Table 2. Parameter results from sorption isotherm modelling of mango skin.

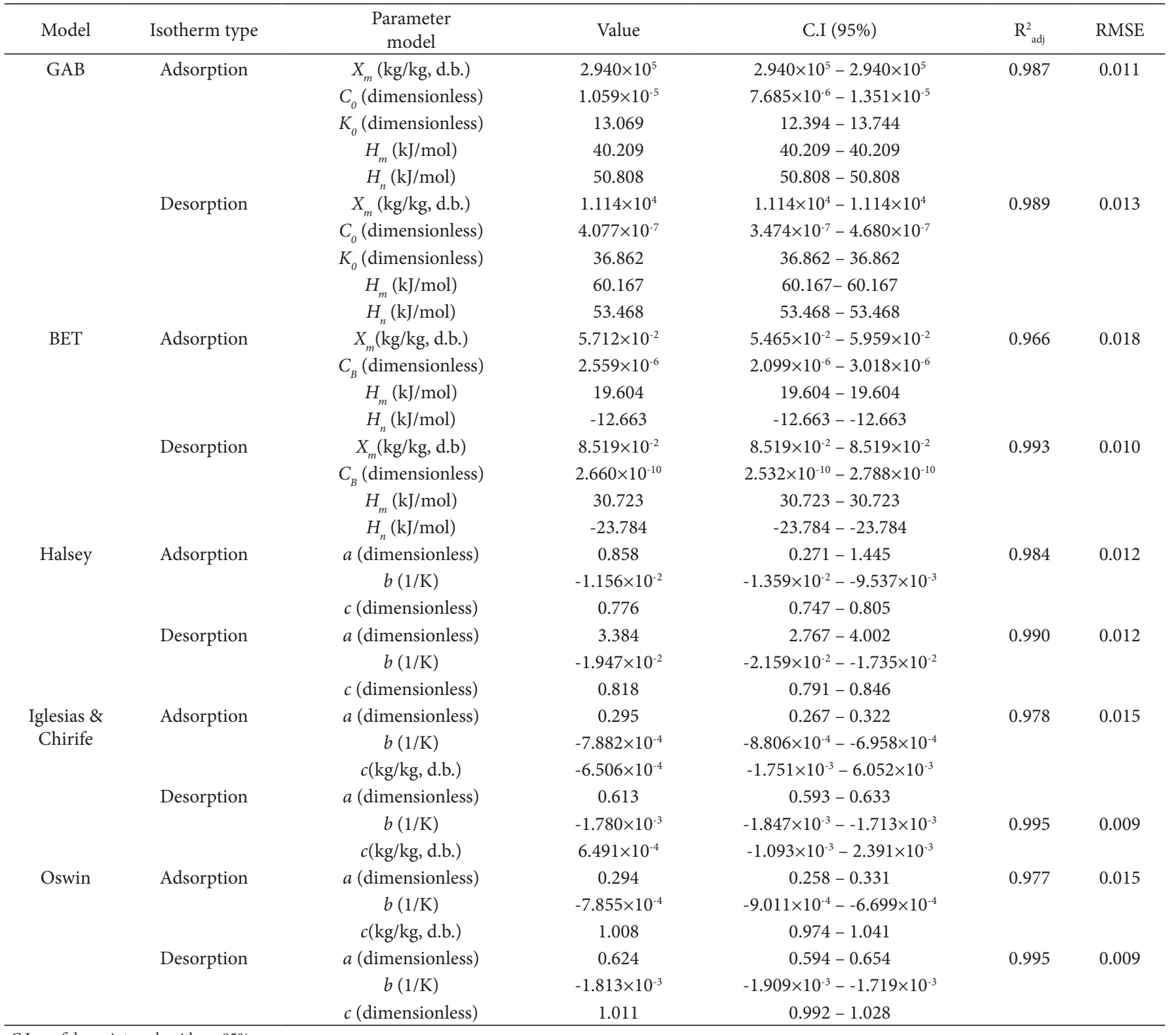

C.I: confidence intervals with $\alpha=95 \%$.

Table 3. Estimated $C$ and $K$ parameters from the GAB equation as a function of temperature.

\begin{tabular}{ccccc}
\hline \multirow{2}{*}{$T\left({ }^{\circ} \mathrm{C}\right)$} & \multicolumn{2}{c}{$\mathrm{C}$} & \multicolumn{2}{c}{$\mathrm{K}$} \\
\cline { 2 - 5 } & Adsorption & Desorption & Adsorption & Desorption \\
\hline 20 & $1.370 \times 10^{-7}$ & $6.368 \times 10^{-6}$ & 0.864 & 0.818 \\
26 & $1.495 \times 10^{-7}$ & $6.026 \times 10^{-6}$ & 0.823 & 0.796 \\
33 & $1.648 \times 10^{-7}$ & $5.666 \times 10^{-6}$ & 0.779 & 0.772 \\
38 & $1.762 \times 10^{-7}$ & $5.432 \times 10^{-6}$ & 0.749 & 0.756 \\
44 & $1.904 \times 10^{-7}$ & $5.172 \times 10^{-6}$ & 0.718 & 0.738 \\
\hline
\end{tabular}

the capillary begins to fill, as the result of increasing water activity, while the pore is still empty. When the partial pressure of the vapour in air becomes larger than the vapour pressure of the liquid in the capillary, the moisture will pass into the pore. For desorption the pore is initially filled with fluid saturation. This liquid can escape only when the pressure of the surrounding air becomes lower than the vapour pressure of liquid inside the capillary.

\subsection{Thermodynamic properties of water sorption}

The integral enthalpy $\left(\Delta H_{i n t}, \mathrm{~J} / \mathrm{mol}\right)$ of water sorption for mango skin was determined using the spreading pressure (Equation 11 by optimizing the derivate water activity from the calculated equilibrium moisture content using the GAB model (Cano-Higuita et al., 2015). The results obtained for adsorption and desorption isotherms are shown in Figure 3, at 20 and $44^{\circ} \mathrm{C}$ as a function of the water activity. 

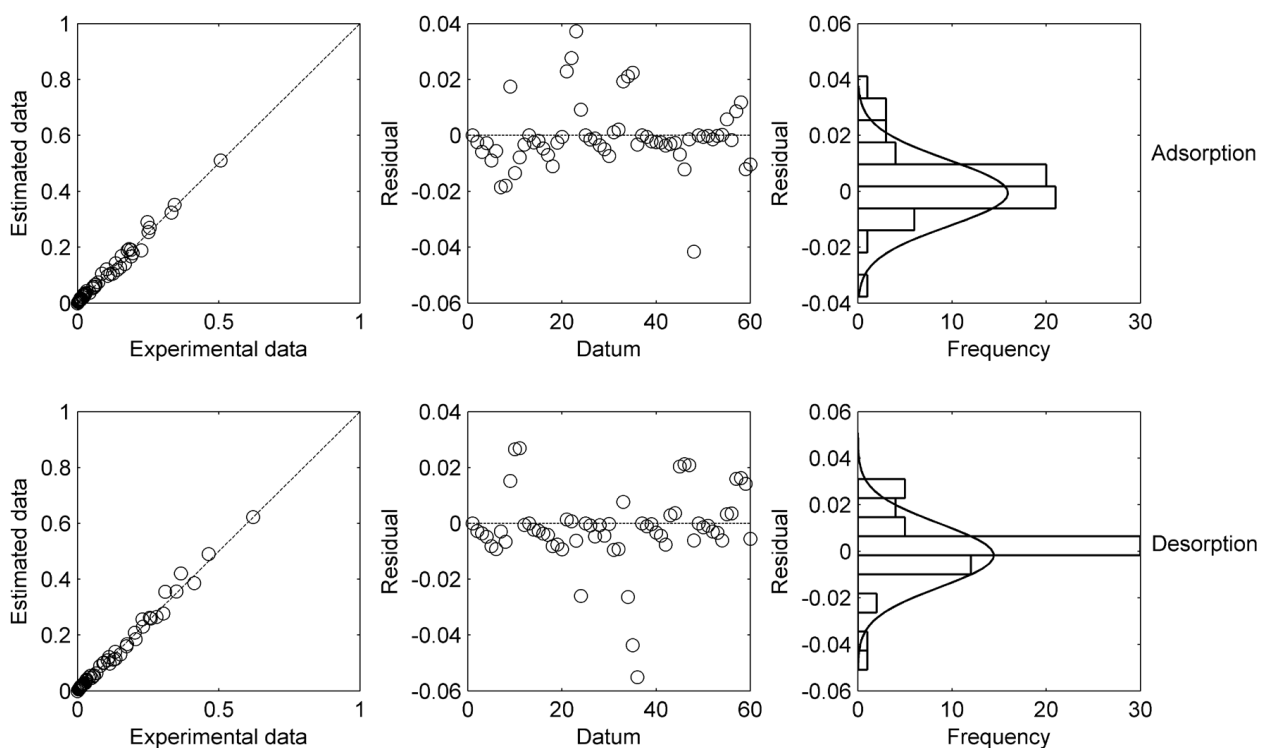

Figure 1. Residual analyses of the experimental and calculated data of equilibrium moisture content for the sorption isotherms of mango skin employing the GAB model.
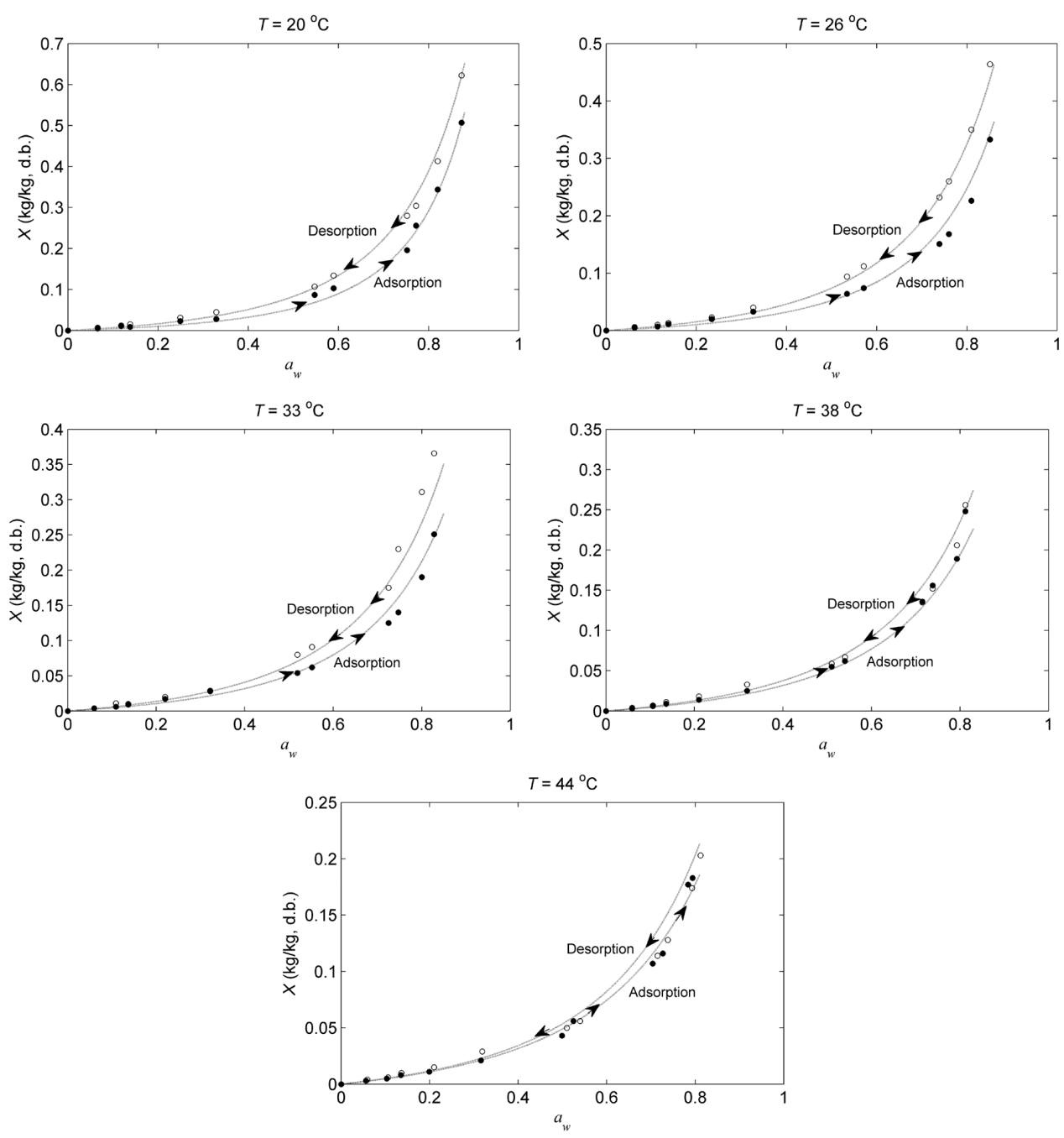

Figure 2. Hysteresis phenomenon behavior using the GAB model (---) at temperatures of $20,26,33,38$ and $44{ }^{\circ} \mathrm{C}$ from adsorption $(\bullet)$ and desorption ( 0 ) data of mango skin. 


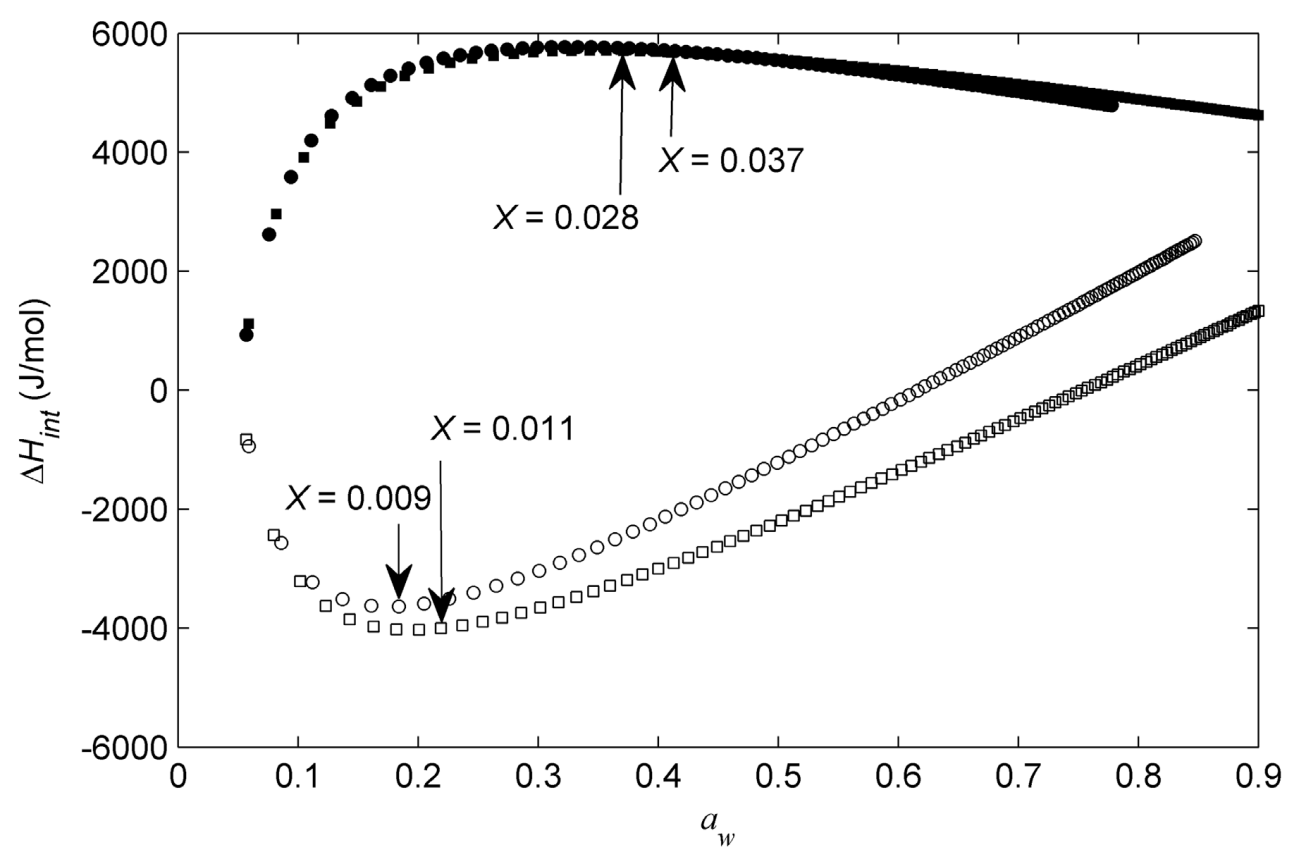

Figure 3. Integral enthalpy for adsorption $\left(20^{\circ} \mathrm{C}(\circ)-44^{\circ} \mathrm{C}(\square)\right)$ and desorption $\left(20^{\circ} \mathrm{C}(\bullet)-44^{\circ} \mathrm{C}(\mathbf{\square})\right)$ isotherms as a function of water activity.

In Figure 3, minimum and maximum peaks in the curves of adsorption and desorption isotherms were found, respectively. Minimum peak of $\Delta H_{\text {int }}$ for the adsorption isotherms curve indicates the location of the bound water and the degree to which the water-solid interaction is higher than the interaction of the water molecules. At this point, the minimum integral enthalpy $\left(\Delta H_{i n t}\right)$ for adsorption was $-3631.5\left(a_{w}=0.184\right)$ and $-4027.4\left(a_{w}=0.226\right) \mathrm{J} / \mathrm{mol}$ at temperatures of 20 and $44{ }^{\circ} \mathrm{C}$. Minimum values of $\Delta H_{\text {int }}$ were found at the moisture content range between 0.009 to $0.011 \mathrm{~kg} / \mathrm{kg}$, d.b. with these places being the most homogeneous in terms of energy and therefore more stable to changes in $a_{w}$. This is because the mango skin is simultaneously subjected to convective drying processes which solubilize sugars from the surface, producing a plasticization effect on the material.

According to Syamaladevi et al. (2010), a slight increase in the water content may produce a large depression of glass transition temperature due to the water plasticization effect. The maximum peaks of the desorption isotherm were $5772.1\left(a_{w}=0.419\right)$ and $5710.8\left(a_{w}=0.379\right) \mathrm{J} / \mathrm{mol}$ at temperatures of 20 and $44{ }^{\circ} \mathrm{C}$. The maximum values of $\Delta H_{\text {int }}$ were found at the moisture content between 0.037 and $0.028 \mathrm{~kg} / \mathrm{kg}$, d.b, for temperatures of 20 and $44^{\circ} \mathrm{C}$, indicating the maximum point of interaction between the water molecules. According to Domínguez et al. (2007), the integral enthalpy is the average energy of all water molecules already bound to the solid at a particular hydration level. Intermediate moisture foods prepared by hydration may be in a glassy state, while a food with an equivalent water activity prepared by dehydration may be in the rubbery state as a result of higher water content.

Similar to the integral enthalpy, the integral entropy $\left(\Delta S_{i n t}, \mathrm{~J} / \mathrm{mol} \mathrm{K}\right)$ was calculated for the adsorption and desorption isotherms at the minimum and maximum temperatures of study $\left(20\right.$ and $44^{\circ} \mathrm{C}$ ) as a function of water activity. Results of $\Delta S_{\text {int }}$ are shown in Figure 4.

In Figure 4 maximum and minimum of $\Delta S_{\text {int }}$ peaks for the adsorption and desorption isotherms were observed. For adsorption isotherm, maximum values of $\Delta S_{i n t}$ of $29.14\left(a_{w}=0.086\right)$ and $29.15\left(a_{w}=0.102\right) \mathrm{J} / \mathrm{mol} \mathrm{K}$ were obtained at 20 and $44^{\circ} \mathrm{C}$. These values of $\Delta$ Sint corresponded to moisture contents from 0.003 to $0.005 \mathrm{~kg} / \mathrm{kg}$, d.b. with this range considered the zone of highest interaction energy for water molecules in the material. $\Delta S_{\text {int }}$ values for $a_{w}$ higher than $0.008 \mathrm{~kg} / \mathrm{kg}$, d.b. can be linked to the enhanced stability or minimum integral entropy for mango skin. For desorption isotherms, values of $\Delta S_{\text {int }}$ of $-13.19\left(a_{w}=0.504\right)$ and $-13.01\left(a_{w}=0.651\right) \mathrm{J} / \mathrm{mol} \mathrm{K}$ were considered the starting point when the $\Delta S_{\text {int }}$ decrease slowly tending to equilibrium at 20 and $44^{\circ} \mathrm{C}$.

These initial points of the minimal $\Delta S_{\text {int }}$ corresponding at the moisture content values of 0.085 to $0.103 \mathrm{~kg} / \mathrm{kg}$ d.b. and these can be considered the best conditions for ensuring mango skin stability during storage. The minimum integral entropy can be interpreted as the required moisture content for forming a monolayer, due to the monolayer corresponding to a small number of configurations in the system (Beristain et al., 2006; Hill et al., 1951). Thus, integral entropy can be qualitatively interpreted in terms of the order-disorder of the adsorbed molecules (Rizvi, 2005). In this work, it is assumed that the maximum stability of mango skin corresponds to the minimum integral entropy zone, since in this zone the water molecules are well organized and less available to participate in reactions of deterioration (Gonelli et al., 2013; Viganó et al., 2012).

The Gibbs free energy $(\Delta G, \mathrm{~kJ} / \mathrm{mol})$ was calculated using Equation 13 in the range of equilibrium water content from 0.00 to $0.40 \mathrm{~kg} / \mathrm{kg}$ d.b. for both sorption isotherms as shown in Figure 5. Maximum values for $\Delta G$ of -5.24 and $-5.91 \mathrm{~kJ} / \mathrm{mol}$ for 


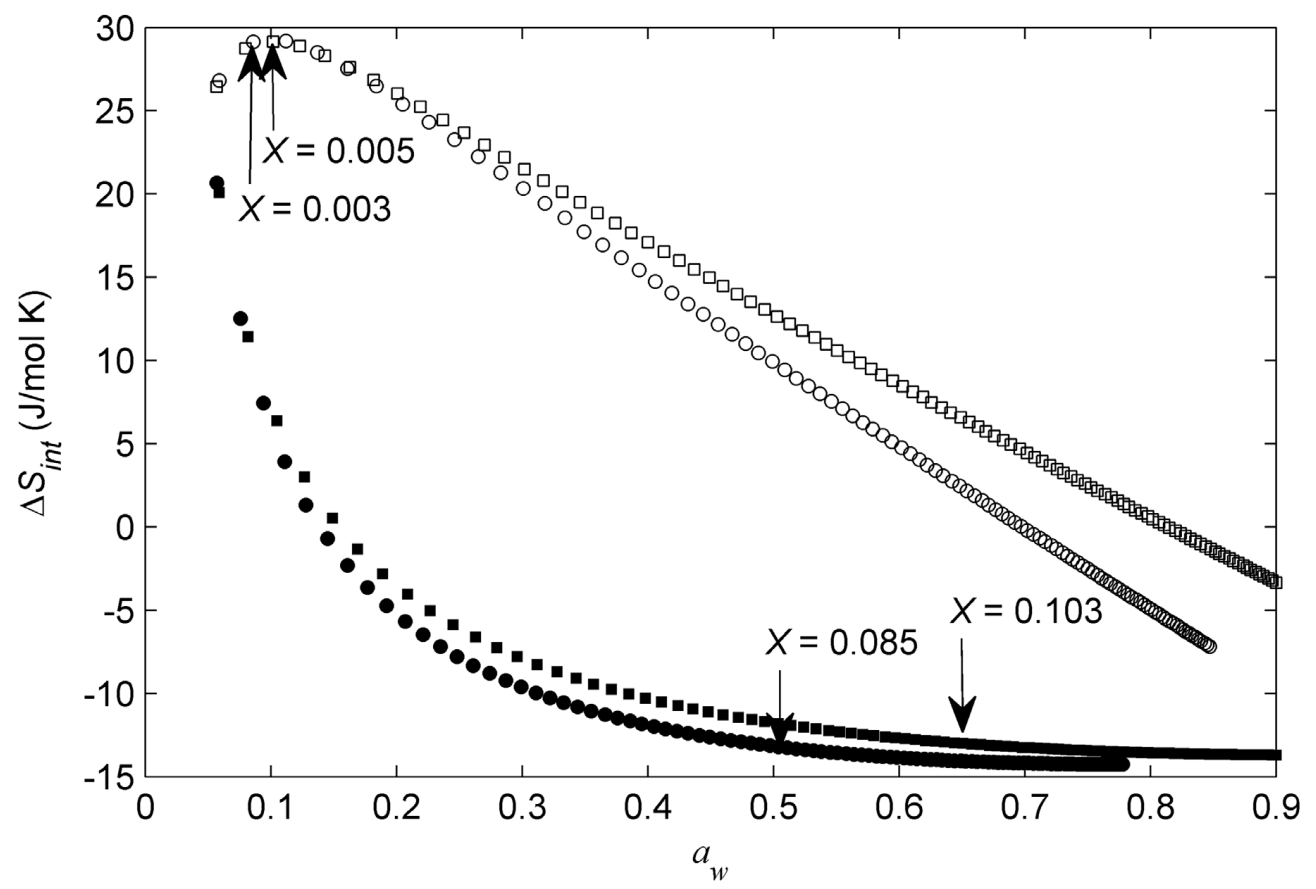

Figure 4. Integral entropy for adsorption $\left(20^{\circ} \mathrm{C}(\circ)-44^{\circ} \mathrm{C}(\square)\right)$ and desorption $\left(20^{\circ} \mathrm{C}(\bullet)-44^{\circ} \mathrm{C}(\boldsymbol{\bullet})\right)$ isotherms as a function of water activity.

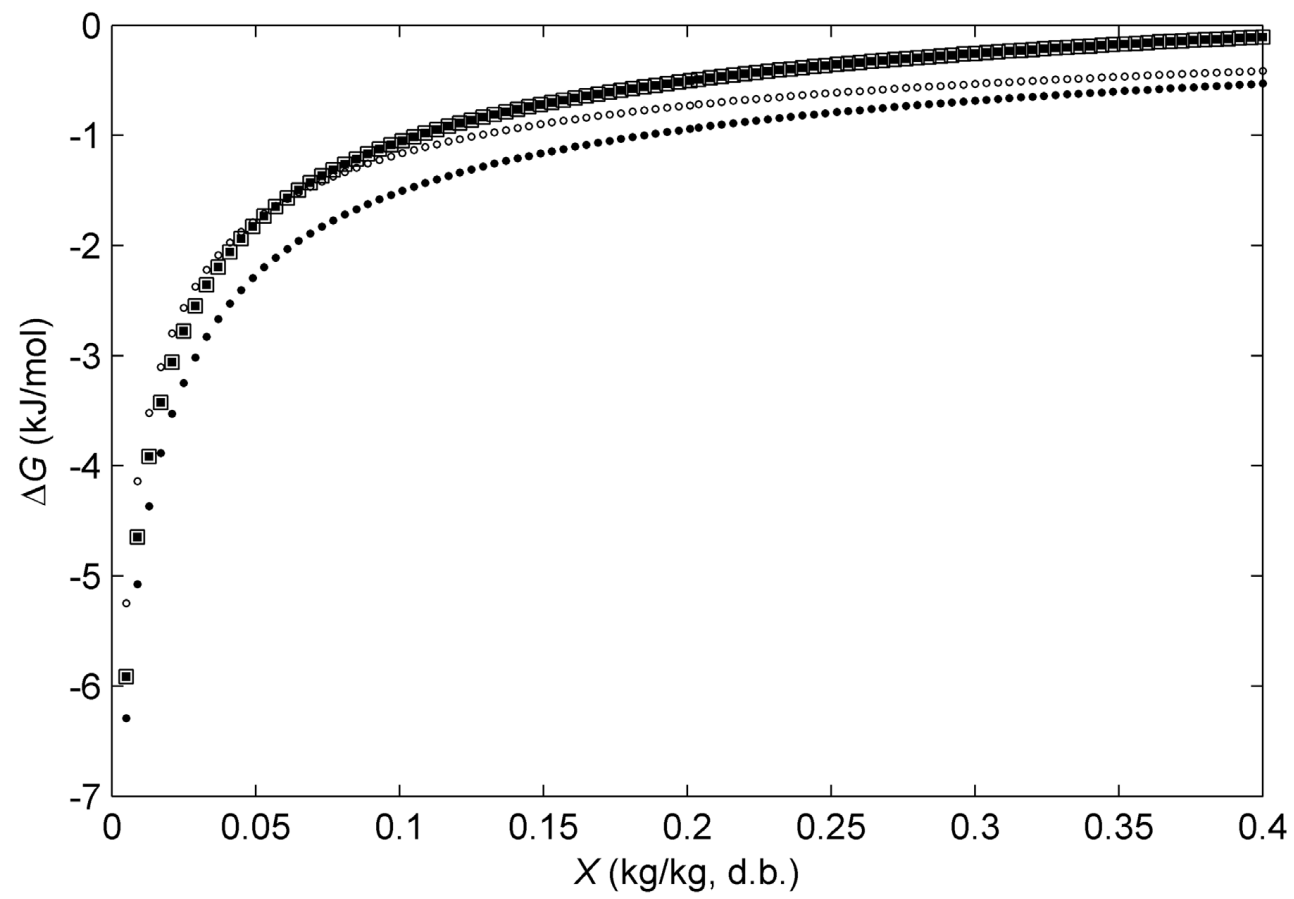

Figure 5. Gibbs free energy for adsorption $\left(20^{\circ} \mathrm{C}(\circ)-44^{\circ} \mathrm{C}(\square)\right)$ and desorption $\left(20^{\circ} \mathrm{C}(\bullet)-44^{\circ} \mathrm{C}(\boldsymbol{\bullet})\right)$ isotherms as a function of equilibrium moisture content.

adsorption isotherm and -6.29 and $-6.05 \mathrm{~kJ} / \mathrm{mol}$ for desorption isotherm were obtained at 20 and $44^{\circ} \mathrm{C}$. These values decrease gradually and when the equilibrium moisture content increased, values were close to zero. Gibbs free energy is related to the reaction process in the sorption layers from material and values of $\Delta G \leq 0$ indicate that the water sorption occurred following a spontaneous process (Rizvi, 2005), showing that the reactions occurring in the microstructure of the product would remain stable throughout the $20-44^{\circ} \mathrm{C}$ temperature range. In addition, as $\Delta G$ tends to 0 with increasing water content, it is possible to conclude that there will be fewer sites available to sorption at the higher water content levels. According to Rizvi (2005), negative values of $\Delta G$ show strong intermolecular interactions or bonding (related to the enthalpy), which would lead to a greater reduction in the freedom of water molecules configuration and hence to a greater order of the system (related to the entropy). 


\section{Conclusions}

The equilibrium moisture content for adsorption and desorption isotherms of mango skin was determined at temperatures from $20-44{ }^{\circ} \mathrm{C}$ and water activities of 0.000 to 0.873 , since the $\mathrm{GAB}$ model showed the best representation of the experimental equilibrium content data and the hysteresis phenomenon in mango skin. The sorption enthalpy referring to the difference between the GAB parameters $H_{m}$ and $H_{n}$ indicates a strong endothermic and exothermic interaction of water vapor with primary sorption sites of the mango skin, respectively. In addition, the integral thermodynamic properties of water sorption at the minimum and maximum temperatures show optimal storage conditions for mango skin. Finally, the results of these properties show the differences between the adsorption isotherm and the desorption isotherm.

\section{Acknowledgements}

The authors are grateful to the financial support received for this project from the São Paulo Research Foundation (FAPESP),process number 2013/17497-5 and to Harvey Alexander Villa-velez, Ph.D., for his support on the experimental procedures.

\section{References}

Ajila, C. M., Bhat, S. G., \& Prasada Rao, U. J. S. (2007). Valuable components of raw and ripe peels from two Indian mango varieties. Food Chemistry, 102(4), 1006-1011. http://dx.doi.org/10.1016/j. foodchem.2006.06.036.

Al Hodali, R. (1997). Numerical simulation of an agricultural foodstuffs drying unit using solar energy and adsorption process ( $\mathrm{PhD}$ Thesis). Université Libre de Bruxelles. Belgium.

Al-Muhtaseb, A. H., McMinn, W. A. M., \& Magee, T. R. A. (2002). Moisture sorption isotherm characteristics of food products: a review. Trans IChemE, 80, 118-128.

Al-Muhtaseb, A. H., McMinn, W. A. M., \& Magee, T. R. A. (2004). Water sorption isotherms of starch powders: part 1: mathematical description of experimental data. Journal of Food Engineering, 61(3), 297-307. http://dx.doi.org/10.1016/S0260-8774(03)00133-X.

Association of Analytical Chemists International - AOAC. (1997). Offical methods of analysis of the Association of Official Analytical Chemists (16th ed.). Gaithersburg, USA: AOAC.

Arslan, N., \& Togrul, H. (2005). Moisture content isotherms for crushed chillies. Biosystems Engineering, 90(1), 47-61. http://dx.doi. org/10.1016/j.biosystemseng.2004.10.008.

Azuara, E., \& Beristain, C. I. (2006). Enthalpic and entropic mechanisms related to water sorption of yogurt. Drying Technology, 24(11), 15011507. http://dx.doi.org/10.1080/07373930600961173.

Bahloul, N., Boudhrioua, N., \& Kechaou, N. (2008). Moisture desorptionadsorption isotherms and isosteric heats of sorption of Tunisian olive leaves (Olea europea L). Industrial Crops and Products, 28(2), 162-176. http://dx.doi.org/10.1016/j.indcrop.2008.02.003.

Beerh, O. P., Raghuramaiah, B., Krishnamurthy, G. V., \& Giridhar, N. (1976). Utilization of mango waste: recovery of juice from waste pulp and peel. Journal of Food Science and Technology, 13, 138-141.

Bejar, A. K., Mihoubi, N. B., \& Kechaou, N. (2012). Moisture sorption isotherms - Experimental and mathematical investigations of orange (Citrus sinensis) peel and leaves. Food Chemistry, 132(4), 1728-1735. http://dx.doi.org/10.1016/j.foodchem.2011.06.059.
Bello-Pérez, L. A., Aparicio-Saguilán, A., Méndez-Montealvo, G., Solorza-Feria, J., \& Flores-Huicochea, E. (2005). Isolation and partial characterization of mango (Magnifera indica L.) starch: morphological, physicochemical and functional studies. Plant Foods for Human Nutrition (Dordrecht, Netherlands), 60(1), 7-12. http:// dx.doi.org/10.1007/s11130-005-2534-z. PMid:15898353

Beristain, C. I., Azuara, E., \& Vernon-Carter, E. J. (2006). Effect of water activity on the stability to oxidation of spray-dried encapsulated orange peel oil using mesquite gum (Prosopis Juliflora) as wall material. Journal of Food Science, 67, 1-6.

Beristain, C. I., Garcia, H. S., \& Azuara, E. (1996). Enthalpy-entropy compensation in food vapor adsorption. Journal of Food Engineering, 30(3-4), 405-415. http://dx.doi.org/10.1016/S0260-8774(96)00011-8.

Bon, J., Váquiro, H. A., Benedito, J., \& Telis-Romero, J. (2010). Thermophysical properties of mango pulp (Mangifera indica L. cv. Tommy Atkins). Journal of Food Engineering, 97(4), 563-568. http:// dx.doi.org/10.1016/j.jfoodeng.2009.12.001.

Brunauer, S., Deming, L. S., Deming, W. E., \& Treller, E. (1940). On the theory of van der waals adsorption of gases. Journal of the American Chemical Society, 62(7), 1723-1732. http://dx.doi.org/10.1021/ ja01864a025.

Cano-Higuita, D. M., Villa-Vélez, H. A., Telis-Romero, J., Váquiro, H. A., \& Telis, V. R. N. (2015). Influence of alternative drying aids on water sorption of spray dried mango mix powders: a thermodynamic approach. Food and Bioproducts Processing, 93, 19-28. http://dx.doi. org/10.1016/j.fbp.2013.10.005.

Domínguez, I. L., Azuara, E., Vernon-Carter, E. J., \& Beristain, C. I. (2007). Thermodynamic analysis of the effect of water activity on the stability of macadamia nut. Journal of Food Engineering, 81(3), 566-571. http://dx.doi.org/10.1016/j.jfoodeng.2006.12.012.

Eim, V. S., Rosselló, C., Femenia, A., \& Simal, S. (2011). Moisture sorption isotherms and thermodynamic properties of carrot. International Journal of Food Engineering, 7(3), 1-18. http://dx.doi. org/10.2202/1556-3758.1804.

Flores-Andrade, E., Beristatin, C. I., Vernon-Carter, E. J., Gutiérrez, G. F., \& Azuara, E. (2009). Entahlpy-entropy compensation and water transfer mechanism in osmotically dehydrated agar gel. Drying Technology: an International Journal, 27(9), 999-1009. http://dx.doi. org/10.1080/07373930902904921.

Gabas, A. L., Telis, V. R. N., Sobral, P. J. A., \& Telis-Romero, J. (2007). effect of maltodextrin and arabic gum in water vapor sorption thermodynamics properties of vacuum dried pineapple pulp powder. Journal of Food Engineering, 82(2), 246-252. http://dx.doi. org/10.1016/j.jfoodeng.2007.02.029.

Gomez-Carracedo, A., Martinez-Pacheco, R., Concheiro, A., \& GomezAmoza, J. L. (2010). Modelling of porosity and waterfronts in cellulosic pellets for understanding drug release behavior. International Journal of Pharmaceutics, 388(1-2), 101-106. http://dx.doi.org/10.1016/j. ijpharm.2009.12.038. PMid:20038448

Gonelli, A. L. D., Corrêa, P. C., Oliveira, G. H. H., \& Afonso-Júnior, P. C. (2013). Water sorption properties of coffe fruits, pulped and green coffe. LWT-Food Science and Technology (Campinas.), 50, 386-391.

Goula, A. M., Karapantsios, T. D., Achilias, D. S., \& Adamopoulos, K. G. (2008). Water sorption isotherms and glass transition temperature of spray dried tomato pulp. Journal of Food Engineering, 85(1), 73-83. http://dx.doi.org/10.1016/j.jfoodeng.2007.07.015.

Hill, T. L., Emmett, P. H., \& Joyner, L. G. (1951). Calculation of thermodynamic functions of absorbed molecules from adsorption isotherms measurements: nitrogen on graphon. The Journal of Chemical Physics, 73, 5102-5107. 
Iglesias, H. A., \& Chirife, J. (1976). Prediction of the effect of temperature on water sorption isotherms of food materials. Journal of Food Technology, 11(2), 109-116. http://dx.doi.org/10.1111/j.1365-2621.1976. tb00707.x.

Jowitt, R., Escher, F., Hallstom, B., Meffert, H. F. T., Spiess, W. E. L., \& Vos, G. (1987). Physical properties methods of foods (2nd ed.). London: Applied Science Publishers.

Kaleemullah, S., \& Kailappan, R. (2004). Moisture sorption of red chillies. Biosystems Engineering, 88(1), 95-104. http://dx.doi.org/10.1016/j. biosystemseng.2004.01.003.

Labuza, T. P., Kaanane, A., \& Chen, J. Y. (1985). Efect of temperature on the moisture sorption isotherms and water activity shift of two dehydrates foods. Journal of Food Science, 50(2), 385-392. http:// dx.doi.org/10.1111/j.1365-2621.1985.tb13409.x.

Larrauri, J. A., Rupérez, P., Borroto, B., \& Saura-Calixto, F. (1996). Mango peels as a new tropical fibre: preparation and characterization. $L W T$ - Food Science and Technology (Campinas.), 29, 729-733.

Majd, K. M., Karparvarfard, S. H., Farahnaky, A., \& Jafarpour, H. (2012). Thermodynamic of water sorption of grape seed: temperature effect of sorption isotherms and thermodynamic characteristics. Food Biophysics, 7, 1-11.

McMinn, W. A. M., Al-Muhtaseb, A. H., \& Magee, T. R. A. (2005). Enthalpy-entropy compensation theory in soprtion phenomena of starch materials. Journal of Food Engineering, 38, 505-510.

Mulet, A., García-Pascual, P., Sanjuán, N., \& García-Reverter, J. (2002). Equilibrium isotherms and isosteric heats of morel (Morchela esculenta). Journal of Food Engineering, 53(1), 75-81. http://dx.doi. org/10.1016/S0260-8774(01)00142-X.

Nezbeda, I., \& Weingerl, U. (2001). A molecular-based theory for the thermodynamic properties of water. Molecular Physics, 99(18), 1595-1606. http://dx.doi.org/10.1080/00268970110064790.

Ojokoh, A. O. (2007). Effect of fermentation on the chemical composition of mango (Mangifera indica R) peels. African Journal of Biotechnology, 6, 1979-1981.

Pagano, A. M., \& Mascheroni, R. H. (2005). Sorption isotherms for amaranth grains. Journal of Food Engineering, 67(4), 441-450. http:// dx.doi.org/10.1016/j.jfoodeng.2004.05.012.

Prette, A. P., Almeida, F. A. C., Villa-Vélez, H. A., \& Telis-Romero, J. (2013). Thermodynamic properties of water sorption of jackfruit (Artocarpus heterophyllus Lam.) as a function of moisture content.
Food Science and Technology (Campinas.), 33(1), 199-208. http:// dx.doi.org/10.1590/S0101-20612013005000030.

Rangel-Marrón, M., Welti-Chanes, J., Córdova-Quiroz, A. V., CerónBretón, J. G., Cerón-Bretón, R. M., \& Anguebes-Franseschi, F. (2011). Estimation of moisture sorption isotherms of mango pulp freeze-dried. International Journal of Biology and Biomedical Engineering, 5, 18-23.

Rizvi, S. S. H. (2005). Thermodynamic properties of foods in dehydration. In M. A. Rao, S. S. H. Rizvi, \& A. K. Datta (Eds.), Engineering Properties of Foods (3th ed., pp. 1-88). Boca Raton: Taylor \& Francis Group.

Samapundo, S., Devlieghere, F., Meulenaer, B., Atukwase, A., Lamboni, Y., \& Debevere, J. M. (2007). Sorption isotherms and isosteric heats of sorption of whole yellow dent corn. Journal of Food Engineering, 79(1), 168-175. http://dx.doi.org/10.1016/j.jfoodeng.2006.01.040.

Syamaladevi, R. M., Sablani, S. S., Tang, J., Powers, J., \& Swanson, B. G. (2010). Water sorption and glass transition temperatures in red raspberry (Rubus idaeus). Thermochimica Acta, 503-504, 90-96. http://dx.doi.org/10.1016/j.tca.2010.03.013.

Telis, V. R. N., Gabas, A. L., Menegalli, F. C., \& Telis-Romero, J. (2000). Water sorption thermodynamic properties applied to persimmon skin and pulp. Thermochimica Acta, 343(1-2), 49-56. http://dx.doi. org/10.1016/S0040-6031(99)00379-2.

Timmermann, E. O., Chirife, J., \& Iglesias, H. A. (2001). Water sorption isotherms of foods and foodstuffs: BET or GAB parameters? Journal of Food Engineering, 48(1), 19-31. http://dx.doi.org/10.1016/S02608774(00)00139-4.

Vaughan, J. G., \& Geissler, C. A. (2009). The new oxford book of food plants. (4a ed.). New York: Oxford University Press.

Viganó, J., Azuara, E., Telis, V. R. N., Beristain, C. I., Jiménez, M., \& Telis-Romero, J. (2012). Role of enthalpy and entropy in mositure sorption behavior of pineapple pulp powder produced by different drying methods. Thermochimica Acta, 528, 63-71. http://dx.doi. org/10.1016/j.tca.2011.11.011.

Villa-Vélez, H. A., Váquiro, H. A., Bon, J., \& Telis-Romero, J. (2012). Modelling thermodynamic properties of banana waste by analytical derivation of desorption isotherms. International Journal of Food Engineering, 8(1), 1-19. http://dx.doi.org/10.1515/1556-3758.2191.

Yan, Z., Sousa-Gallagher, M. J., \& Oliveira, F. A. R. (2008). Sorption isotherms and moisture sorption hysteresis of intermediate moisture content banana. Journal of Food Engineering, 86(3), 342-348. http:// dx.doi.org/10.1016/j.jfoodeng.2007.10.009. 